\title{
JAFRe \\ ANALISIS PERKEMBANGAN KEMAMPUAN KEUANGAN DAERAH DALAM MENDUKUNG PELAKSANAAN OTONOMI DAERAH DI KABUPATEN LUWU UTARA
}

\author{
Elvin Bosso ${ }^{1}$, Fina Diana ${ }^{2}$, A. Asirah ${ }^{3}$ \\ ${ }^{123}$ Universitas Patria Artha \\ Fina71diana@gmail.com ${ }^{1}$
}

\begin{abstract}
This study aims to determine the level of development of financial capacity in North Luwu Regency in order to support the implementation of regional autonomy. The analytical method used in this research is descriptive and quantitative analysis methods. The data used is secondary data from related government agencies, namely regarding the Regional Revenue and Expenditure Budget (APBD) in the 2016-2019 period. The results of the descriptive analysis show that from 2016-2019 the income of Kab. North Luwu continues to experience an increase. This is because the percentage of increase in regional income has increased which is almost close to the percentage of increase in regional spending. When viewed from the results of the quantitative analysis, it can be concluded that Kab. North Luwu has not been financially able to finance its own governmental activities in its region. This can be seen from the low proportion of PAD to TPD from 2016-2019, with an average of 20.59\%. District self-reliance ratio calculation. North Luwu shows an average yield of 6.35\%. This illustrates that Kab. North Luwu has a pattern of instructive relationships, where financial dependence on the central government is still very high.
\end{abstract}

Keywords: DDF; Regional Tax and Retribution Performance Indicators; Regional Financial Independence

\begin{abstract}
ABSTRAK
Penelitian ini bertujuan untuk mengetahui tingkat perkembangan kemampuan keuangan di Kabupaten Luwu Utara dalam rangka mendukung pelaksanaan Otonomi daerah. Metode analisis yang digunakan dalam penelitian ini adalah metode analisis deskriptif dan kuantitatif. Data yang digunakan merupakan data sekunder dari instansi pemerintah terkait, yakni mengenai Anggaran Pendapatan dan Belanja Daerah (APBD) dalam kurun waktu 2016-2019. Hasil analisis deskriptif menunjukkan bahwa dari tahun 2016-2019 pendapatan Kab. Luwu Utara terus mengalami peningkatan, Ini disebabkan karena prosentase peningkatan pendapatan daerah mengalami peningkatan yang hampir mendekati prosentase peningkatan belanja daerah. Adapun jika dilihat dari hasil analisis kuantitatifnya, dapat disimpulkan bahwa Kab. Luwu Utara belum mampu secara keuangan dalam membiayai sendiri kegiatan penyelenggaraan pemerintahan di daerahnya. Ini terlihat dari masih rendahnya proporsi PAD terhadap TPD dari tahun 2016-2019, dengan rata-rata sebesar 20,59\%. Perhitungan rasio kemandirian Kab. Luwu Utara menunjukkan hasil rata-rata sebesar 6,35\%. Hal tersebut menggambarkan bahwa Kab. Luwu Utara memiliki pola hubungan instruktif, dimana ketergantungan finansial terhadap pemerintah pusat masih sangat tinggi.
\end{abstract}

Kata kunci: DDF; Indikator Kinerja Pajak dan Retribusi Daerah; Kemandirian Keuangan Daerah 


\section{PENDAHULUAN}

Kabupaten Luwu Utara adalah salah satu Daerah Tingkat II di provinsi Sulawesi Selatan, Indonesia. Ibu kota kabupaten ini terletak di Masamba. Kabupaten Luwu Utara yang dibentuk berdasarkan UU No. 19 tahun 1999 merupakan pecahan dari Kabupaten Luwu.Pada tahun 1999, saat awal bergulirnya Reformasi di seluruh wilayah Republik Indonesia, dimana telah dikeluarkannya UU No.22 Tahun 1999 tentang Pemerintahan di Daerah, dan mengubah mekanisme pemerintahan yang mengarah pada Otonomi Daerah.

Dalam pelaksanaan Otonomi Daerah terdapat empat elemen penting yang diserahkan Pemerintah Pusat kepada Pemerintah Daerah. Ke empat elemen tersebut yaitu Desentralisasi Politik, Desentralisasi Fiskal, Desentralisasi Administrasi dan Desentralisasi Ekonomi "menurut Cheema dan Rondinelli. Keempat elemen tersebut menjadi kewajiban daerah untuk mengelola secara efisien dan efektif. Sehingga dengan demikian akan terjadi kemampuan / kemandirian suatu daerah untuk melaksanakan fungsinya dengan baik. Salah satu elemen yang diserahkan pemerintah pusat kepada pemerintah daerah adalah desentralisasi fiskal.
Desentralisasi fiskal yang merupakan komponen utama dari desentralisasi pelaksanaan otonomi daerah dan menandai dimulainya babak baru dalam pembangunan daerah serta masyarakatnya dalam mengelola sumber daya / segenap potensi yang dimiliki untuk mewujudkan kesejahteraan dan kemajuan daerah.

Dengan adanya otonomi daerah, kewenangan yang dimiliki oleh pemerintah daerah akan semakin besar sehingga tanggung jawab yang diembannya akan bertambah banyak. Implikasi dari adanya kewenangan urusan pemerintahan yang begitu luas yang diberikan kepada daerah dalam rangka otonomi daerah dapat menjadi suatu berkah bagi daerah. Namun disisi lain bertambahnya kewenangan daerah tersebut juga merupakan beban yang menuntut kesiapan daerah untuk pelaksanaannya, karena semakin besar urusan pemerintah yang menjadi tanggung jawab pemerintah daerah. Oleh karena itu ada beberapa aspek yang harus dipersiapkan antara lain sumber daya manusia, sumber daya keuangan, sarana dan prasarana daerah. Aspek keuangan merupakan salah satu dasar kriteria untuk dapat mengetahui secara nyata kemampuan daerah dalam mengurus rumah tangganya sendiri. Kemampuan 
daerah yang dimaksud adalah sampai sejauh mana daerah dapat menggali sumber-sumber keuangan sendiri guna membiayai kebutuhan keuangan daerah tanpa harus menggantungkan diri pada bantuan dan subsidi dari pemerintah pusat.

Kita perlu mengetahui perkembangan perkembangan kemampuan keuangan Kab. Luwu Utara karena dalam pelaksanaan otonomi daerah Kab. Luwu Utara, keuangan menjadi faktor penting yang perlu mendapat perhatian serius. Sehubungan dengan hal itu perlu dilakukan penilaian kinerja serta kemampuan keuangan pemerintah daerah untuk mengetahui perkembangan pengelolaan keuangan daerahsetiap tahunnya, apakah mampu menunjang Otonomi daerah di Kabupaten Luwu Utara atau tidak.

Tabel 1

\section{Kondisi Desentralisasi Fiskal Kabupaten}

Luwu Utara 4 Tahun Terakhir 2016-2019

\begin{tabular}{cc}
\hline Tahun & $\begin{array}{c}\text { DF(\%) } \\
\text { PAD/TPD }\end{array}$ \\
\hline 2016 & 25,41 \\
2017 & 16,68 \\
2018 & 21,15 \\
2019 & 19,12 \\
\hline Rata-rata & 20,59 \\
\hline Sumber : Hasil Olahan Data Sekunder
\end{tabular}

Dari tabel di atas dapat dilihat bahwa rasio PAD terhadap TPD mengalami penurunan satu tahun terakhir yaitu tahun 2016 ke tahun 2017 akan tetapi di tahun 2018 mengalami kenaikan dari angka 16,86 ke 21,15 tetapi kembali mengalami penurunan di tahun 2019 menjadi 19,12. Hasil rasio PAD terhadap TPD tertinggi adalah di tahun 2016 dengan nilai sebesar 25,41 dan yang terendah adalah di tahun 2017 dengan nilai sebesar 16,68. Jika dilihat secara rata-rata, hasil rasionya adalah 20,59. Dengan penurunan nilai rasio PAD terhadap TPD ini dan berdasarkan ratarata dari tahun 2016-2019, menunjukkan kemampuan keuangan kab. Luwu Utara dapat dikatakan belum mandiri.

Kemampuan pemerintah daerah Kab. Luwu Utara dalam mengelola keuangan tercermin dalam Anggaran Pendapatan Belanja Daerah (APBD) yang menggambarkan kemampuan pemerintah daerah dalam membiayai kegiatan pelaksanaan tugas pembangunan, serta pemerataan dan keadilan dengan mengembangkan seluruh potensi yang dimiliki oleh masing-masing daerah. Salah satu ciri utama daerah mampu dalam melaksanakan otonomi daerah adalah terletak pada kemampuan keuangan daerah untuk membiayai penyelenggaraan pemerintahan daerahnya dengan tingkat ketergantungan kepada 
pemerintah pusat mempunyai proporsi yang semakin mengecil dan diharapkan bahwa PAD harus menjadi bagian terbesar dalam memobilisasi

dana penyelenggaraan pemerintah daerah. Pendapatan Asli Daerah merupakan salah satu faktor yang penting dalam pelaksanaan roda pemerintahan suatu daerah yang berdasar pada prinsip otonomi yang nyata, luas dan bertanggung jawab. Peranan Pendapatan Asli Daerah dalam keuangan daerah menjadi salah satu tolak ukur penting dalam pelaksanaan otonomi daerah, dalam arti semakin besar suatu daerah memperoleh dan menghimpun PAD maka akan semakin besar pula tersedianya jumlah keuangan daerah yang dapat digunakan untuk membiayai penyelenggaraan Otonomi Daerah

\section{TINJAUAN PUSTAKA}

\section{Otonomi Daerah}

Menurut pasal 1 UU No. 32 Tahun 2004, Otonomi Daerah adalah hak, wewenang, dan kewajiban daerah otonom untuk mengatur dan mengurus sendiri urusan pemerintahan dan kepentingan masyarakat setempat sesuai dengan peraturan perundang-undangan.

Menurut Suparmoko (2010:18) Otonomi Daerah adalah kewenangan daerah otonom untuk mengatur dan mengurus kepentingan masyarakat setempat menurut prakarsa sendiri berdasarkan aspirasi masyarakat.

Secara etimologis, kata otonomi berasal dari bahasa latin: auto berarti sendiri dan nomein berarti peraturan, atau undang-undang. Maka autonom berarti mengatur sendiri, atau memerintah sendiri, atau dalam arti luas adalah hak untuk mengatur dan mengurus rumah tangga daerah sendiri (Winarna Surya Adi Subrata, 2013). Sedangkan yang dimaksud dengan Daerah Otonom adalah kesatuan masyarakat hukum yang mempunyai batas-batas wilayah yang berwenang mengatur dan mengurus urusan pemerintahan dan kepentingan masyarakat setempat menurut prakarsa sendiri berdasarkan aspirasi masyarakat dalam sistem Negara Kesatuan Republik Indonesia.

$$
\text { Prinsip otonomi daerah }
$$
menggunakan prinsip otonomi seluasluasnya dalam arti daerah diberikan kewenangan mengurus dan mengatur semua urusan pemerintah diluar yang menjadi urusan pemerintah yang ditetapkan dalam Undang-Undang. Daerah memiliki kewenangan membuat kebijakan daerah untuk memberi pelayanan, meningkatkan peran serta, prakarsa, dan 
pemberdayaan masyarakat yang bertujuan pada peningkatan kesejahteraan rakyat. (Undang-Undang Nomor 32 Tahun 2004).

Dalam Undang-Undang No. 32 tahun 2004 pasal 1 ayat 6 menyebutkan bahwa daerah otonomi selanjutnya disebut daerah adalah kesatuan masyarakat yang mempunyai batas-batas wilayah yang berwenang mengatur dan mengurus urusan pemerintahan dan kepentingan masyarakat setempat menurut prakarsa sendiri berdasarkan aspirasi masyarakat dalam sistem Negara kesatuan Republik Indonesia.

\section{Hakekat Otonomi Daerah}

Pelaksanaan otonomi daerah pada hakekatnya adalah upaya untuk meningkatkan kesejahteraan masyarakat dengan melaksanakan kegiatan-kegiatan pembangunan sesuai dengan kehendak dan kepentingan masyarakat. Berkaitan dengan hakekat 18 otonomi daerah tersebut yang berkenaan dengan pelimpahan wewenang pengambilan keputusan kebijakan, pengelolaan dana publik dan pengaturan kegiatan dalam penyelenggaraan pemerintah dan pelayanan masyarakat maka peranan data keuangan daerah sangat dibutuhkan untuk mengidentifikasi sumber-sumber pembiayaan daerah serta jenis dan besar belanja yang harus dikeluarkan agar perencanaan keuangan dapat dilaksanakan secara efektif dan efisien.

\section{Tujuan Otonomi Daerah}

Menurut Mardiasmo Otonomi dan Manajemen Keuangan Daerah bertujuan untuk meningkatkan pelayanan publik (public service) dan memajukan perekonomian daerah. Tujuan otonomi daerah menurut penjelasan Undangundang No 32 tahun 2004 pada dasarnya adalah sama yaitu otonomi daerah diarahkan untuk memacu pemerataan pembangunan dan hasil-hasilnya, meningkatkan kesejahteraan 19 rakyat, menggalakkan prakarsa dan peran serta masyarakat secara nyata, dinamis, dan bertanggung jawab sehingga memperkuat persatuan dan kesatuan bangsa, mengurangi beban pemerintah pusat dan campur tangan di daerah yang akan memberikan peluang untuk koordinasi tingkat lokal.

\section{Prinsip Otonomi Daerah}

Menurut penjelasan UndangUndang No. 32 tahun 2004, prinsip penyelenggaraan otonomi daerah adalah :

1. Penyelenggaraan otonomi daerah dilaksanakan dengan aspek demokrasi, 
keadilan, pemerataan serta potensi dan keaneka ragaman daerah.

2. Pelaksanaan otonomi daerah didasarkan pada otonomi luas, nyata dan bertanggung jawab.

3. Pelaksanaan otonomi daerah yang luas dan utuh diletakkan pada daerah kabupaten dan daerah kota, sedangkan otonomi provinsi adalah otonomi yang terbatas.

4. Pelaksanaan otonomi harus sesuai dengan konstitusi negara sehingga tetap terjamin hubungan yang serasi antara pusat dan daerah.

5. Pelaksanaan otonomi daerah harus lebih meningkatkan kemandirian daerah kabupaten dan daerah kota tidak lagi wilayah administrasi. Demikian pula di kawasan-kawasan khusus yang dibina oleh pemerintah.

6. Pelaksanaan otonomi daerah harus lebih meningkatkan peranan dan fungsi badan legislatif daerah baik sebagai fungsi legislatif, fungsi pengawasan, mempunyai fungsi anggaran atas penyelenggaraan otonomi daerah.

7. Pelaksanaan dekonsentrasi diletakkan pada daerah propinsi dalam kedudukan sebagai wilayah administrasi untuk melaksanakan kewenangan pemerintah tertentu dilimpahkan kepada gubernur sebagai wakil pemerintah.

8. Pelaksanaan asas tugas pembantuan dimungkinkan tidak hanya di pemerintah daerah dan daerah kepada desa yang disertai pembiayaan, sarana dan prasarana serta sumber daya manusia dengan kewajiban melaporkan pelaksanaan dan mempertanggung jawabkan kepada yang menugaskan.

\section{Keuangan Daerah}

Menurut Mamesah dalam Halim (2014;23-25) Keuangan Daerah adalah semua hak dan kewajiban yang dapat dinilai dengan uang, demikian pula segala sesuatu baik berupa uang maupun barang yang dapat dijadikan kekayaan daerah sepanjang belum dimiliki/ dikuasai oleh negara atau daerah yang lebih tinggi serta pihakpihak lain sesuai dengan ketentuan perundangundangan yang berlaku.

Kemampuan Keuangan Daerah
adalah kemampuan keuangan daerah
dalam mebiayai urusan-urusan rumah
tanggaya, khususnya yang berasal dari
pendapatan aseli daerah. Pendapatan Aseli daerah sampai saat ini merupakan sektor yang sangat diharapkan dan diandalkan oleh pemerintah daerah. 
Dalam

penyelenggaraan

diperlukan usahausaha

meningkatkan

sendiri dengan

kemampuan

mengupayakan

peningkatan penerimaan

PAD.

Peningkatan PAD dapat dilakukan dengan meningkatkan peneriman sumber PAD yang sudah ada maupun dengan menggali sumber PAD yang baru sesuai dengan ketentuan yang ada serta memperhatikan kondisi dan potensi ekonomi masyarakat (Halim,2014:91).

\section{Teori Kemampuan Keuangan Daerah}

Menurut Hikma (2012) untuk melihat kemampuan keuangan daerah dalam menjalankan otonomi daerah, salah satunya dapat di ukur melalui kinerja keuangan daerah.

Ciri utama yang menunjukkan suatu daerah otonom mampu berotonomi adalah terletak pada kemampuan keuangan daerah untuk membiayai penyelenggaraan pemerintahan daerahnya dengan tingkat ketergantungan kepada pemerintah pusat yang mempunyai proporsi semakin kecil. Oleh karena itu, diharapkan PAD dapat menjadi bagian terbesar dalam memobilisasi dana penyelenggaraan pemerintahan daerah.

\section{METODE PENELITIAN}

\section{Metode Analisis}

Teknik analisis data yang digunakan dalam penelitian ini adalah analisis deskriptif kuantitatif, yakni analisis yang digunakan untuk mengetahui besarnya Pendapatan Asli Daerah (PAD) yang kemudian dapat untuk menghitung tingkat Efektivitas Pajak Daerah terhadap Pendapatan Asli Daerah (PAD).

Analisis data yang digunakan terdiri dari:

1. Rasio Kemandirian Keuangan Daerah, rasio ini menunjukkan tingkat kemampuan suatu daerah dalam membiayai sendiri kegiatan pemerintah, pembangunan dan pelayanan kepada masyarakat yang telah membayar pajak dan retribusi sebagai sumber pendapatan yang diperlukan daerah:

$$
\begin{gathered}
\text { Rasio kemandirian }=\frac{\text { Pendapatan Asli Daerah }}{\text { Sumber Pendapatan Dari pihak Ekstern }} \\
\text { Sumber: Mudrajat,2005 }
\end{gathered}
$$


2. Rasio derajat desentralisasi fiskal, guna membiayai pembangunan. rasio ini mengukur kemampuan Derajat Desentralisasi Fiskal dapat pemerintah daerah dalam rangka dihitung dengan menggunakan rumus meningkatkan Pendapatan Asli daerah sebagai berikut:

$$
D D F=\frac{\text { PADt }}{\text { TPDt }} \times 100 \%
$$

Keterangan :

DDF : Derajat Desentralisasi Fiskal

PADt : Total PAD tahun $\mathrm{t}$

TPDt : Total Penerimaan Daerah Tahun $\mathrm{t}$

Sumber : Tiyaningsih 2009:39

Tabel 2

Skala Interval Derajat Desentralisasi Fiskal

\begin{tabular}{cc}
\hline DDF $(\boldsymbol{\%})$ & Keterangan \\
\hline $0,00-10,00 \%$ & Sangat kurang \\
$10,01-20,00 \%$ & Kurang \\
$20,01-30,00 \%$ & Sedang \\
$30,01-40,00 \%$ & Cukup \\
$40,01-50,00 \%$ & Baik \\
$>50,00 \%$ & Sangat baik \\
\hline
\end{tabular}

Sumber: Hanafi dan Mugroho (2005:80)

HASIL PENELITIAN DAN PEMBAHASAN

\section{Derajat Desentralisasi Fiskal (DDF)}

Perhitungan Derajat Desentralisasi

Fiskal (DDF) dapat dilakukan dengan menggunakan (3) formula, yakni rasio antara Pendapatan Asli Daerah (PAD) dengan Total pendapatan Daerah (TPD), rasio Bagi Hasil pajak dan bukan pajak (BHPBP) dengan TPD dan rasio sumbangan dan bantuan Daerah (SBD) dengan TPD. Jika hasil rasio antara PAD dengan TPD maupun BHPBP dengan TPD lebih dari 50\% maka kemampuan keuangan daerah dikatakan belum mandiri.

Sedangkan untuk rasio antara SBD dengan TPD, jika nilainya lebih dari $50 \%$ maka tingkat ketergantungan finansial terhadap pemerintah pusat berkurang. 
Tabel 3

Derajat Desentralisasi Fiskal Kabupaten Luwu Utara Tahun 2016-2019

\begin{tabular}{cccc}
\hline \multirow{2}{*}{ Tahun } & \multicolumn{3}{c}{ DDF (\%) } \\
\cline { 2 - 4 } & PAD/TPD & BHPBP/TPD & SBD/TPD \\
\hline 2016 & 25,41 & 18,31 & 8,33 \\
2017 & 16,68 & 19,71 & 3,82 \\
2018 & 21,15 & 15,21 & 3,86 \\
2019 & 19,12 & 13,84 & 3,73 \\
\hline Rata-rata & 20,59 & 16,76 & 4,93 \\
\hline
\end{tabular}

Sumber: Hasil Ringkasan Pengolahan Data Sekunder

Dari tabel di atas dapat dilihat adalah pada tahun 2019 sebesar 13,84 bahwa rasio PAD terhadap TPD secara rata-rata dari tahun 2016-2019, mengalami penurunan satu tahun terakhir hasil rasio BHPBP terhadap TPD adalah yaitu tahun 2016 ke tahun 2017 akan sebesar 16,76\%.Dengan nilai yang masih tetapi di tahun 2018 mengalami kenaikan kurang dari 50\% maka dapat dikatakan dari angka 16,86 ke 21,15 tetapi kembali kemampuan keuangan Kab. Luwu Utara mengalami penurunan di tahun 2019 belum mandiri.

menjadi 19,12. Hasil rasio PAD terhadap TPD tertinggi adalah di tahun 2016 dengan nilai sebesar 25,41 dan yang terendah adalah di tahun 2017 dengan nilai sebesar 16,68. Jika dilihat secara rata-rata, hasil rasionya adalah 20,59. Dengan penurunan nilai rasio PAD terhadap TPD ini dan berdasarkan ratarata dari tahun 2016-2019, menunjukkan kemampuan keuangan kab. Luwu Utara dapat dikatakan belum mandiri.

Untuk rasio BHPBD terhadap TPD, sama seperti rasio PAD terhadap TPD yang telah disebutkan sebelumnya, nilai maksimalnya adalah pada tahun 2017 sebesar 19,71 sedangkan yang terendah Adapun hasil perhitungan DDF yang ketiga, yakni rasio antara SBD terhadap TPD, nilai tertingginya adalah 8,33 pada tahun 2016 dan nilai terendah 3,73 pada tahun 2019. Sedangkan untuk rata-rata dari tahun 2016-2019, hasil rasio menunjukkan angka 4,93. Karena nilainya yang berada di bawah 50\%, maka hal ini mengindikasi bahwa ketergantungan pemerintah daerah Kab. Luwu Utara terhadap pemerintah pusat masih sangat tinggi sehingga tingkat desentralisasi fiskalnya masih rendah, belum ada kemandirian. 
Indikator Kinerja pajak dan Retribusi Daerah

Pos Pajak dan Retribusi merupakan pos yang memberikan sumbangan relatif besar terhadap PAD. Untuk mengetahui kinerja / kemampuan Pajak dan Retribusi dalam menghasilkan PAD, dapat diketahui dengan melihat besarnya Rasio pengumpulan, pertumbuhan, maupun proporsi (Kontribusi) Pajak serta Retribusi Daerah. Semakin besar nilainya maka semakin besar pula kemampuan Pajak dan
Retribusi Daerah dalam menghasilkan PAD.

\section{Rasio pengumpulan}

Rasio pengumpulan (collection Ratio) Pajak dan Retribusi diperoleh dari perbandingan antara realisasi penerimaan pajak dan Retribusi dengan targetnya. Rasio pengumpulan ini digunakan untuk mengukur efektivitas realisasi penerimaan pajak dan Retribusi di wilayah Kab. Luwu Utara.

Tabel 4

Rasio Pengumpulan Pajak Kabupaten Luwu Utara Tahun 2016-2019

\begin{tabular}{llrlc}
\hline \multirow{2}{*}{ Tahun } & \multicolumn{2}{c}{ Maksimal } & \multicolumn{2}{c}{ Minimal } \\
\cline { 2 - 4 } & \multicolumn{1}{c}{ Jenis pajak } & Nilai (\%) & \multicolumn{1}{c}{ Jenis pajak } & $\begin{array}{c}\text { Nilai } \\
(\%)\end{array}$ \\
\hline 2016 & P.Reklame & 189,40 & P. Hiburan & 62,41 \\
2017 & P.Restoran & 132,97 & P. Bumi \& Bangunan & 97,30 \\
2018 & P.Reklame & 120,27 & P.Mineral & 49,46 \\
2019 & P. Bumi \& Bangunan & 101,98 & P. Mineral & 35,84 \\
\hline
\end{tabular}

Sumber: Hasil olahan Data sekunder

Dari tabel 4 dapat diketahui bahwa ada 2 macam pajak yang memiliki rasio pengumpulan pajak tertinggi selama 2 Tahun dicapai oleh Pajak Reklame yakni di tahun 2016,2018. Secara keseluruhan rasio pengumpulan tertinggi dari tahun 2016-2019 dicapai oleh pajak Reklame pada tahun 2016 dengan nilai sebesar $189,40 \%$. Tetapi pada tahun 2019, rasio pengumpulan pajak Mineral menjadi yang terendah dibandingkan pajak-pajak lainnya. ada 3 pajak yang dikategorikan belum efektif karena nilai rasionya yang masih di bawah 100\%, yakni pajak Hiburan Selama 1 Tahun dimana rasio pengumpulannya hanya sebesar $62,41 \mathrm{di}$ tahun 2016, kemudian Pajak Bumi dan Bangunan pengumpulan Rasionya hanya 
sebesar 97,30 di Tahun 2017, dan yang terendah terakhir yaitu pajak Mineral juga selama 2 Tahun berturut-turut dimana Rasio pengumpulannya hanya sebesar 49,46 \& 35,84. Ini menunjukkan bahwa target penerimaan pajak yang telah di tetapkan sebelumnya belum dapat tercapai. Sehingga pajak ini dapat di kategorikan belum efektif.

Tabel 5

Rasio Pengumpulan Retribusi Kabupaten Luwu Utara Tahun 2016-2019

\begin{tabular}{clclc}
\hline \multirow{2}{*}{ Tahun } & \multicolumn{2}{c}{ Maksimal } & \multicolumn{2}{c}{ Minimal } \\
\cline { 2 - 5 } 2016 & Jenis Retribusi & Nilai (\%) & \multicolumn{1}{c}{ Jenis Retribusi } & Nilai (\%) \\
\hline \multirow{2}{*}{2017} & Ret. Izin Trayek & 132,50 & $\begin{array}{l}\text { Ret. Tempat Rekreasi \& } \\
\text { Olah Raga }\end{array}$ & 54,14 \\
2018 & Ret. Pemakaian & 122,45 & Ret. Izin Trayek & 39,90 \\
& Kekayaan Daerah & 125,97 & Ret. Izin Trayek & 29,00 \\
2019 & $\begin{array}{l}\text { Ret. Pelayanan } \\
\text { Tera/Tera Ulang }\end{array}$ & \multirow{2}{*}{127,71} & Ret. Izin Trayek & 37,00 \\
\hline
\end{tabular}

Sumber: Hasil Ringkasan Pengolahan Data Sekunder

Berbeda dengan pajak, rasio retribusi terjadi pada tahun 2018 dengan pengumpulan retribusi baik yang jenis retribusi ijin trayek, sebesar $29,00 \%$. mencapai nilai tertinggi maupun yang terendah dari tahun 2016-2019 selalu berbeda. Jika dilihat secara keseluruhan, nilai tertinggi untuk rasio pengumpulan retribusi dicapai pada tahun 2016 dengan jenis retribusi pelayanan pencegahan bahaya kebakaran $(132,50 \%)$. Sedangkan nilai terendah untuk rasio pengumpulan

\section{Analisis Kontribusi}

Analisis Kontribusi digunakan untuk mengetahui besarnya tingkat kontribusi masing-masing pos pajak dan retribusi daerah Kab. Luwu Utara terhadap total penerimaan pajak dan retribusi daerah. 
Elvin Bosso dkk, Analisis Perkembangan Kemampuan Keuangan Daerah

Tabel 6

Kontribusi Pajak Kabupaten Luwu Utara Tahun 2016-2019

\begin{tabular}{ccccc}
\hline \multirow{2}{*}{ Tahun } & \multicolumn{2}{c}{ Maksimal } & \multicolumn{2}{c}{ Minimal } \\
\cline { 2 - 5 } & Jenis Pajak & Nilai (\%) & Jenis Pajak & Nilai (\%) \\
\hline 2016 & PPJ & 104,76 & P.Parkir & 0,24 \\
2017 & PPJ & 100,09 & P.Parkir & 0,27 \\
2018 & PPJ & 101,27 & P.Parkir & 0,87 \\
2019 & PPJ & 87,64 & P.Parkir & 1,32 \\
\hline
\end{tabular}

Sumber: Hasil Ringkasan Pengolahan Data Sekunder

Berdasarkan tabel 6 di atas dapat sebesar 104,76\%. Sedangkan pajak diketahui bahwa besar kontribusi realisasi dengan kontribusi terendah dari tahun pajak terhadap total pajak Kota Surakarta 2016-2019 adalah pajak parkir. Meski dari tahun 2016-2019 yang terbesar adalah nilai kontribusinya terhadap total pajak Pajak Penerangan Jalan (PPJ) dengan nilai adalah terendah, tetapi dari tahun ke tahun maksimal di tahun 2016 dengan kontribusi nilai kontribusinya terus bertambah.

Tabel 7

Kontribusi Retribusi Kabupaten Luwu Utara Tahun 2016-2019

\begin{tabular}{ccccc}
\hline \multirow{2}{*}{ Tahun } & \multicolumn{2}{c}{ Maksimal } & \multicolumn{2}{c}{ Minimal } \\
\cline { 2 - 5 } & Jenis Pajak & Nilai (\%) & Jenis Pajak & Nilai (\%) \\
\hline 2016 & Ret. Pasar & 99,68 & Sewa gedung/Aula & 50,00 \\
2017 & Ret. Pasar & 105,23 & Dinas perhubungan & 39,90 \\
2018 & Ret. Pasar & 89,68 & PT. Bank sulsel & 47,04 \\
2019 & Ret. Pasar & 90,47 & Pendapatan UPTD & 49,49 \\
& & & Transfusi Darah & 4 \\
\hline
\end{tabular}

Sumber: Hasil Ringkasan Pengolahan Data Sekunder

Tabel 7 tampak bahwa dari tahun 2016- 2019 jenis retribusi yang memberikan kontribusi terbesar terhadap total retribusi Kab. Luwu Utara adalah retribusi pasar. Hal ini karena di wilayah Kab. Luwu Utara terdapat banyak pasar, antara lain pasar Sukamaju dan Pasar Bone-Bone, (Pasar induk) Pasar Sentral dan sebagainya. Dengan banyaknya pedagang di dalam pasar-pasar tersebut, maka akan memperbesar nilai penerimaan retribusi daerah dan berdampak pada meningkatnya PAD Kab. Luwu Utara. 
Kemandirian Keuangan Daerah dan

\section{Pola Hubungan}

Kemandirian keuangan daerah menunjukkan kemampuan Pemerintah Daerah dalam membiayai sendiri penyelenggaraan pemerintahan, pembangunan dan pelayanan kepada masyarakat. Kemandirian keuangan daerah dapat juga menggambarkan sampai seberapa besar tingkat ketergantungan finansial Pemerintah Daerah terhadap Pemerintah Pusat. Kemandirian keuangan daerah Kab. Luwu Utara dihitung dengan membandingkan penerimaan PAD terhadap penerimaan Bantuan dan Sumbangan Daerah.

Mengenai pola hubungan keuangan antara Pemerintah Pusat dan Pemerintah Daerah, ada 4 hubungan situasional yang dapat digunakan dalam pelaksanaan otonomi daerah (Paul Hersey dan Kenneth Blanchard dalam Abdul halim 2014: 188), yaitu: 1) Pola Hubungan Instruktif, dimana peranan Pemerintah Pusat lebih dominan daripada kemandirian Pemerintah Daerah (daerah yang tidak mampu melakasanakan otonomi daerah), 2) Pola Hubungan Konsultatif, dimana campur tangan Pemerintah Pusat sudah mulai berkurang karena daerah dianggap sedikit lebih mampu melaksanakan otonomi, 3) Pola Hubungan Partisipatif, dimana peran Pemerintah Pusat semakin berkurang, mengingat daerah yang bersangkutan tingkat kemandiriannya mendekati mampu melaksanakan otonomi daerah. 4) Pola Hubungan Delegatif, dimana campur tangan Pemerintah Pusat sudah tidak ada karena daerah telah benar-benar mampu dan mandiri dalam melaksanakan otonomi daerah.

Bertolak dari teori di atas, karena adanya potensi Sumber Daya Alam (SDA) dan Sumber Daya Manusia (SDM) yang berbeda akan menyebabkan perbedaan dalam tingkat kemandirian daerah dan pola hubungan antar daerah terhadap Pemerintah Pusat. Sebagai pedoman dalam melihat hubungan dengan kemampuan daerah dari sisi keuangannya dapat dilihat dari tabel berikut: 
Tabel 8

Tingkat Kemampuan Keuangan, Kemandirian dan Pola Hubungan

\begin{tabular}{ccc}
\hline Kemampuan Keuangan & Kemandirian $(\%)$ & Pola Hubungan \\
\hline Rendah sekali & $0-25$ & Instruktif \\
Rendah & $25-50$ & Konsultatif \\
Sedang & $50-75$ & Partisipatif \\
Tinggi & $75-100$ & Delegatif \\
\hline
\end{tabular}

Sumber: Abdul Halim, 2014

Menurut hasil perhitungan tingkat tahun 2016-2019 dapat dilihat pada tabel 9 kemandirian daerah Kab. Luwu Utara dari berikut:

Tabel 9

Tingkat Kemandirian, Kemampuan Keuangan dan Pola Hubungan Kab. Luwu Utara Selama Kurun Waktu 2016- 2019

\begin{tabular}{|c|c|c|c|c|}
\hline Tahun & PAD & $\begin{array}{c}\text { Dana } \\
\text { Perimbangan }\end{array}$ & $\begin{array}{c}\text { Tingkat } \\
\text { Kemandirian } \\
\text { Daerah } \\
\end{array}$ & $\begin{array}{c}\text { Pola } \\
\text { Hubungan }\end{array}$ \\
\hline 2016 & 95.629 .729 .228 & 1.032 .042 .523 .220 & 1,07 & Instruktif \\
\hline 2017 & 107.496.739.626 & 926.995 .330 .000 & 8,62 & Instruktif \\
\hline 2018 & 112.679 .614 .314 & 938.091 .935 .000 & 8,32 & Instruktif \\
\hline 2019 & 128.591 .057 .371 & 954.246 .708 .000 & 7,42 & Instruktif \\
\hline \multicolumn{3}{|c|}{ Rata-rata } & 6,35 & Instruktif \\
\hline
\end{tabular}

Sumber: Hasil Ringkasan Pengolahan Data Sekunder

Tabel 9 dapat terlihat bahwa hubungan yang bersifat instruktif terhadap kemandirian daerah Kab. Luwu Utara pemerintah pusat, dimana peranan dalam mencukupi kebutuhan pembiayaan pemerintah pusat lebih dominan dibanding untuk melakukan tugas-tugas kemandirian pemerintah daerah.

pemerintahan, pembangunan dan pelayanan sosial masyarakat masih sangat KESIMPULAN rendah dan bahkan dari tahun 2017 sampai tahun 2019 cenderung mengalami penurunan. Karena nilai rata-ratanya yang menunjukkan prosentase di bawah $25 \%$, ini berarti Kab. Luwu Utara memiliki pola Pertumbuhan APBD Perhitungan APBD Kab. Luwu Utara dari tahun 2016 sampai dengan tahun 2018 memperlihatkan adanya Defisit anggaran . 
Sedangkan pada tahun 2019 justru terjadi Surplus anggaran karena prosentase peningkatan jumlah Pendapatan daerah 7,96 yang lebih besar daripada prosentase peningkatan Belanja daerah yang hanya sebesar $3,27 \%$.

Kontribusi PAD terhadap APBD Dari tahun 2016-2019, kontribusi PAD terhadap APBD terus mengalami peningkatan. Namun di tahun 2017-2018 tidak memiliki kontribusi atau biasa disebut dengan Stagnan. Hal ini menunjukkan semakin besarnya kontribusi selain PAD dalam menyumbang pendapatan daerah, misalnya saja bantuan dari pemerintah pusat ataupun pemerintah yang lebih tinggi. Derajat Desentralisasi Fiskal (DDF) Dari perhitungan DDF, yakni rasio antara PAD, BHPBP dan SBD terhadap TPD, menunjukkan bahwa secara rata-rata dari tahun 2016-2019 nilai kontribusi PAD terhadap TPD lebih dominan, dibandingkan kontribusi BHPBP \& SBD terhadap TPD. Persentase yang di hasilkan hanya mencapai $13,46 \%$ tidak dapat mencapai 50,00\% hal ini mengindikasikan ketergantungan Pemerintah Daerah Kab. Luwu Utara terhadap Pemerintah Pusat sangat tinggi sehingga belum ada kemandirian. Rasio kemandirian daerah yang menggambarkan sampai seberapa besar tingkat ketergantungan financial pemerintah daerah terhadap pemerintah pusat, diperoleh dengan membandingkan penerimaan PAD terhadap penerimaan Bantuan dan Sumbangan Daerah. Dari tahun 2016- 2019, Rata-rata perhitungan rasio kemandirian Kab. Luwu Utara menghasilkan nilai $6,35 \%$. Karena nilainya yang berada di antara 0\%-25\%, maka Kab. Luwu Utara dianggap memiliki kemampuan keuangan yang rendah sekali dan mempunyai pola hubungan instruktif terhadap pemerintah pusat, yang mana ketergantungan finansial terhadap pemerintah pusat masih sangat tinggi dibandingkan kemandirian daerahnya.

\section{DAFTAR PUSTAKA}

Adisubrata, Winarna Surya. 2013. Perkembangan Otonomi Daerah di Indonesia (Sejak Proklamasi Sampai Awal Reformasi) 1. Semarang: CV. Aneka

Ilmu.

Arif dan Hakim, Rahman. 2015. "Evaluasi Kemandirian Daerah Dalam PelaksanaanOtonomi Daerah Wilayah SUBOSUKAWONOSRATEN Propinsi JawaTengah (Tinjauan Keuangan Daerah)". DinamikaJurnal EkonomiPembangunan FEUNS Vol. 1, No. 1, 61-72. 
Gusti Ayu Sonia Wina Laksmi dan Ni Luh Supadmi. 2014. Efektivitas Pemungutan Pendapatan Asli Daerah dan Konntribusinya padaPendapatan Daerah.

E-Jurnal Akuntansi Universitas Udayana.

Halim, Abdul. 2014. Manajemen Keuangan Daerah (Edisi Revisi). Yogyakarta: UPP AMP YKPN.

Halim, Abdul dan Damayanti,Theresia. 2014. Pengelolaan Keuangan Daerah. Yogyakarta: UPP STIM YKPN.

Mardiasmo. 2012. Otonomi dan Manajemen Keuangan Daerah. Yogyakarta: Penerbit Andhi. Jurnal EL-Riyasah

Mujiwardhani, Alfian. 2011. "Analisis Kemandirian Daerah Kabupaten Cilacap

Sebelum dan Selama Otonomi Daerah (Tinjauan Keuangan Daerah)".

Skripsi FE UNS Surakarta. Tidak dipubikasikan.

Muslim. 2011. Mengenal Kepopuleran Otonomi di Indonesia Pasca Bergulirnya Reformasi.

Sanny Wurangian Daisy S.M. 2017. Analisis Kemampuan Keuangan
Daerah Dalam Pelaksanaan

Otonomi Daerah Di Kota Tomohon. Jurnal Berkala Ilmiah Efisiensi Volume 17 No. 01

Savitry, Ermhita. 2011. Analisis Kemampuan Keuangan Daerah dalam Pelaksanaan Otonomi Daerah Tahun 2007-2011 di Kota Makassar. Jurnal Ilmu Pemerintahan Volume 4, Nomor 1.

Sumodiningrat. 2011. Analisis Laporan Keuangan APBD. Boyolali: Tidak dipublikasikan.

Suparmoko. 2010:18 .(Teori Otonomi daerah) Tidak di publikasikan.

Suryanto. 2014 Sistem Pengelola Keuangan Daerah Medan: Tidak dipublikasikan.

Yuwono, Sonny. 2018. Memahami APBD dan Permasalahannya (Panduan Pengelolaan Keuangan Daerah). Malang: Bayumedia Publishing.

2004. Undang-Undang No. 32 Tahun 2004, Otonomi Daerah adalah hak, wewenang, dan kewajiban daerah otonom untuk mengatur dan mengurus sendiri urusan pemerintahan dan kepentingan masyarakat setempat sesuai dengan peraturan perundang-undangan 